\title{
Analysis of the effect of credit on the crop output of rice farmers in Benue State, Nigeria
} Okolo Samson Ayegba, Olotu Olafemi Ayopo

Department of Agribusiness; Federal University of Agriculture Makurdi Corresponding author. Email: $\underline{\text { samdivine147@gmail.com }}$

\begin{abstract}
The study was conducted to analyze the effect of credit on crop output of rice farmers in Benue state, Nigeria. Random and stratified sampling method was used to select 236 respondents in the study area. Out of the selected respondents only 208 responded and submitted the administered well-structured questionnaires correctly. Therefore, the study was based on 208 primary data collected from registered Savings and Credit Cooperative (SACCO) members in the three Local Government Areas of Benue State. In this study the year 2011 was used for before credit was obtained and 2015 for after credit was obtained. Descriptive statistics Foster-Greer-Thorbecke (FGT) poverty measure and double difference estimator was used to analyze the data collected. The analysis showed that $60.2 \%$ and $67.5 \%$ which is majority are male beneficiaries and non-beneficiaries of credit respectively. The active age of the rice farmers were 31-40years and 41-50years for beneficiaries and non-beneficiaries respectively. The result from poverty severity index showed that $3 \%$ of the beneficiaries constitute the poorest after obtaining credit and 5\% of the non-beneficiaries constitute the poorest also in the same year 2015. The result of the double difference estimate showed that the SACCO credit had a positive effect on the crop output of the beneficiaries of the credit with crop output mean value of $1176.84 \mathrm{~kg}$. SACCO executives and the Government should develop strategies that will bring in more funding, loans and grants to the cooperative consequently enhance availability of credit to members. This will help members who are smallholder farmers to become big estate farm holders. It is also possible that more credit availability to members is a key to poverty reduction due to its positive effect on the crop output as seen in the study.
\end{abstract}

Keywords-Analysis; effect of credit; crop output; rice farmers; poverty status; Benue State.

\section{INTRODUCTION}

Poverty is a major scourge on farmers and low level income earners in Benue state. Benue state is known to be a state engaging more than 70 percent of its population in agriculture; agriculture is the back bone of the economy of the state (Ajaero, 2007). The performance in agriculture is relatively average and dwindling due to the poor agricultural finance. The research on the poverty reduction among rice farmers is very important since rice is a major staple in the study area.

Rice is consumed by more than 4.8 billion people in 176 countries and is the most important food crop for over 2.89 billion people in Asia, over 40 million people in Africa and over 150.3 million people in America, (Biyi, 2005). According to Jones, (1995), rice is the second most important cereal in the world after wheat in terms of production; while Nigeria ranks the highest as both producer and consumer of rice in the West Africa sub region. Akande and Akpokodje
(2003) opined that, since the mid-1970s, rice consumption in Nigeria has risen tremendously, at about $10 \%$ per annum due to changing preferences while domestic production has never been able to meet the demand leading to considerable imports which today stands at about 1,000,000 metric tons yearly. The imports are procured on the world market with Nigeria spending annually over US $\$ 300$ million on rice imports alone. Similarly, Biyi (2005) observed that the annual domestic output of rice still hovers around 3 million metric tons, leaving the huge gap of about 2 million metric tons annually, a situation, which has continued to encourage dependence on importation. This calls for the need to finance the rice farmers via the umbrella of the savings and credit cooperatives. With adequate financing of the SACCO it is very possible to meet the demand for rice in Nigeria and subsequently reduce poverty from rice farm families.

Therefore, the need for farmers to come together and form an autonomous association of individuals, voluntarily united 
to meet their common economic, social and cultural needs through a jointly-owned and democratically controlled enterprise (International cooperative alliance, 1996). According to the global Multidimensional Poverty Index, International Monetary Fund (IMF) report by the United Nations (2015) the national average of poverty rate is $46.0 \%$, the national proportion of those living above the poverty line is $54 \%$. Benue State ranked $24^{\text {th }}$ amongst the states living above the poverty line with $40.8 \%$ above the line and about $59.2 \%$ living below the poverty line.

Savings and credit Cooperatives (SACCO) are important in the provision of financial and banking services to low income households who for economic reasons cannot be covered by the activities of formal banks and financial institutions (Mwakajuilo, 2011). SACCO performs three major functions in relations to its members and general economic development of the country. These functions are collecting savings, giving credit and giving financial and non- financial advice to its members in order to facilitate and ensure that SACCO members utilize the micro credit they have borrowed from SACCO.

In some cases, some government and private institutions may also give financial assistance to SACCO in order to enable them give micro credit to their members (Mwakajumilo, 2011). He further posited that the different activities done by households in both urban and rural areas also mean the existence of different SACCO with the aim of assisting the Government to reduce high level of poverty and income inequality in the society.

Unemployment breeds a lot of private and social consequences which are negative (Alam, Khalifa, and Shahjamal, 2009; Alam, 2009). These include poverty, crime, social inequality, loss of output, family disintegration, among others. Governments all over the world make concerted efforts to mitigate these problems (Alam, 2009). In Nigeria several efforts have been made to create jobs for the teaming able bodied people who are available for work but who are yet to find jobs (Goodluck, 2011). One key source of unemployment in Nigeria is dearth of capital required to combine with other factors of production, which are land, labor and entrepreneurship (Nieman, Hough, and Niewenhuizen, 2003). Although growth is critical for poverty reduction, focus on growth alone is not enough (Almas, 2013). Micro-lending has been considered as the latest panacea for poverty alleviation (Magbagbeola, Adetoso, and Owolabi, 2010). Cooperative societies all over the world have been seen as one of the ways of reaching out to the unbanked and the neglected in the society and not a few have come to see it as an alternative to the regular banking, since it, in most case provides members of the group with the financial incentives without the rigors usually experienced in banking halls (Adewakun, 2012). Traditional cooperatives are common throughout Nigeria, but these groups tend to be small, with a common bond based on membership of a kinship, societal and low professional group (Adewakun, 2012). Saving and credit cooperatives Societies are known to provide funding to their members at reasonable interest rate and without requirement of collateral. They are therefore vital organs for financing food crop production (Mavimbela, Masuku, and Belete, 2010).

\section{Objectives of the study}

i. Describe the socio economic characteristics of beneficiaries and non-beneficiaries of SACCO Credit in the study areas;

ii. Determine the poverty status of beneficiaries and non-beneficiaries of SACCO credit;

iii. Analyze the effect of credit on the crop output of beneficiaries and non-beneficiaries of SACCO credit;

Statement of Hypothesis

The use of credit had no significant effect on crop output of beneficiaries of SACCO credit.

\section{METHODOLOGY}

\section{Study Area}

Benue State, the State lies between Latitudes $6^{0} 25^{\prime} \mathrm{N}$ and $8^{0} 8^{\prime} \mathrm{N}$ of the equator and Longitudes $7^{0} 47^{\prime}$ and $10^{\circ} \mathrm{E}$. (Ministry of land and survey, 2016). It has a total land-area of about 33,955 square kilometers with a population of $4,253,641$ (NPC, 2006), with an average population density of 99 persons per square kilometer. The State is blessed with a great loamy soil for agricultural activities. It is one of the 36 states of Nigeria, It comprises 23 Local Government Areas (LGAs) grouped into 3 agricultural zones; A, B, C, respectively. The major food crops produced are yam, rice, cassava, maize, soybean, sesame, cowpea and groundnut at subsistence level. At the end of 2011, the poverty rate of Benue State was estimated at 31.9\% (National Bureau of Statistics, 2012). Meanwhile at the end of 2015 the poverty rate of Benue State was estimated to be $59.2 \%$ based on data collected between 2004 and 2014 (Multidimensional Poverty Index, 2015) published by the United Nations.

There are areas of low population density such as Guma, Gwer East, Ohimini, Katsina-ala, Apa, Logo, and Agatu, each with less than seventy persons per square kilometers, while Vandeikya, Okpokwu, Ogbadibo, Obi, and Gboko 
have density ranging from 140 persons to 200 persons per square kilometer. Makurdi LGA has over 380 persons per square kilometers. The study used zones $(\mathrm{A}, \mathrm{B}, \mathrm{C})$ in the State to ease sample design and research instrument distribution. Zone A had the following Local Government Areas: Katsina- ala, Konshisha, Kwande, Logo, Ukum, Ushongo,Vandeikya. Zone B comprises Buruku, Gboko, Guma, Gwer- West, Gwer and Makurdi LGAs. Lastly Zone C comprises Agatu, Apa, Obi, Oju, Ogbadibo, Okpokwu, Otukpo LGAs.

\section{Population and Sampling Procedures}

Three Local Government Areas where rice cultivation was considerably high were selected, each from an agricultural zone in the State. The questionnaire was distributed to few active rice cooperatives whose major focus was solely on rice farming. The active rice cooperatives are distributed in the three LGAs viz; 9 in Katsina Ala, 82 in Makurdi and 10 in Agatu respectively. From these we have the following population for each LGA who are active with members participation measured by their contributions; Katsina Ala423 cooperators, Makurdi- 621 cooperators and Agatu- 167 cooperators Desk officer rice cooperative societies BSMANR, (2017). From the cooperatives actively participating in rice farming, few cooperatives that were accessible filled the questionnaire distributed, the following sample frame were taken: Katsina Ala with 80 registered member rice farmers, Makurdi with 123 registered member rice farmers and Agatu with 63 registered member rice farmers all with beneficiaries and non-beneficiaries inclusive respectively. A random sampling technique was used to select respondents for this study. The first stage was done by the selection of these three (3) local government areas because of the availability of more members of Savings and Credit Cooperative (SACCO) with documented records among the three agricultural zones of the state. At the end of the questionnaire administration, out of the 236 questionnaire administered, 208 were correctly filled and returned. Therefore the analysis was based on 208 completed rice farmers data collected. 128 of the beneficiaries and 80 of the non-beneficiaries of SACCO credit made up the 208 completed questionnaires.

\section{Data Collection and Analysis}

Primary data was used for this study. These were collected with the aid of structured questionnaire. Data was collected from 236 rice farmers using a structured questionnaire. Out of the 236 questionnaire 208 were retrieved correctly completed. Information collected include: the demographic details of beneficiaries and non-beneficiaries of SACCO credit. The outputs of the rice crop grown by the respondents were determined in Kilogram. Descriptive statistics to analyze the demography of the sample, Foster -Greer Thorbecke (FGT) poverty measure was used to analyze the poverty status of respondents and the double difference estimator was used to analyze the effect of credit on farm output, t-test was used to test the hypothesis.

\section{Model Specification}

\section{Double difference estimator}

Information on both beneficiaries and non-beneficiaries was provided for before and after obtaining credit, it is literally a "difference of difference" (Albouy, 2010). The output of the rice crop grown by the respondents was determined in $\mathrm{kg}$.

A positive mean double difference indicates a credit effect on beneficiaries, while a negative mean double difference indicates that the credit had no effect on beneficiaries (Nkonya et al., 2008) the model is specified as:

$\mathrm{DDE}=\left[\left(\frac{1}{p} \sum_{i}^{p}\left(\bar{Y}_{t i a}-\bar{Y}_{t i b}\right)\right)-\left(\frac{1}{c} \sum_{j}^{c}\left(\bar{Y}_{\text {oja }}-\right.\right.\right.$ $\left.\left.\left.\bar{Y}_{o j b}\right)\right)\right]$

Where;

$\bar{Y}_{t i a}-\bar{Y}_{t i b}=$ difference of mean crop output of beneficiaries after and before obtaining credit respectively.

$\bar{Y}_{o j a}-\bar{Y}_{o j b}=$ difference of mean crop output of non beneficiaries after and before obtaining credit respectively.

$\mathrm{P}=$ number of beneficiaries

$\mathrm{C}=$ number of non- beneficiaries

DDE $=$ the difference between the mean changes in crop output for beneficiaries and non- beneficiaries. If the double difference estimates of the crop output of beneficiaries and non-beneficiaries of SACCO credit is a positive value. Then credit will have positive change on the rice output of beneficiaries.

\section{RESULT AND DISCUSSION}

\section{Socio-Economic Characteristics of Respondents}

An analysis of the sex of respondents indicated that majority (60.2 percent) where male, while 39.8 percent were females among the beneficiaries of SACCO credit. 67.5 percent and 32.5 percent were male and female non-beneficiaries of SACCO credit respectively. This could be because rice crop farming operations are so laborious such that the male who naturally are stronger seems to cope better than their female counterpart. The result agrees with the findings of Oguntola (1988) and Olorunsanya (2009) who concluded that farming 
is male dominated profession and female are however more involved in processing of agricultural products. Another reason for the male dominance could be that most women in the study area do not take farming seriously like the males do. Therefore the SACCO is dominated by male since one of the major objectives of the participation in the rice farmers SACCO is to improve members' livelihood via upscale of rice production.

The result shows that most (48.4 percent) of the beneficiaries and (40 percent) of the non-beneficiaries were between the age of 31-40years for beneficiaries and 41-50years for non- beneficiaries respectively. The mean age of beneficiaries and non-beneficiaries is 45 years. With this age distribution, the indication is that majority of the beneficiaries and nonbeneficiaries were within their active and productive working age. Therefore they participate and earn income from rice farming and other non-farming activities. This finding is in accordance with the findings of Windapo and Olewu (2001) and Bzugu et al., (2005) that productive and active persons participate more in agricultural and community development activities and groups such as SACCO.

Table 1 Socio-Economic Characteristics of the beneficiaries and Non-beneficiaries of credit

$$
(n=208)
$$

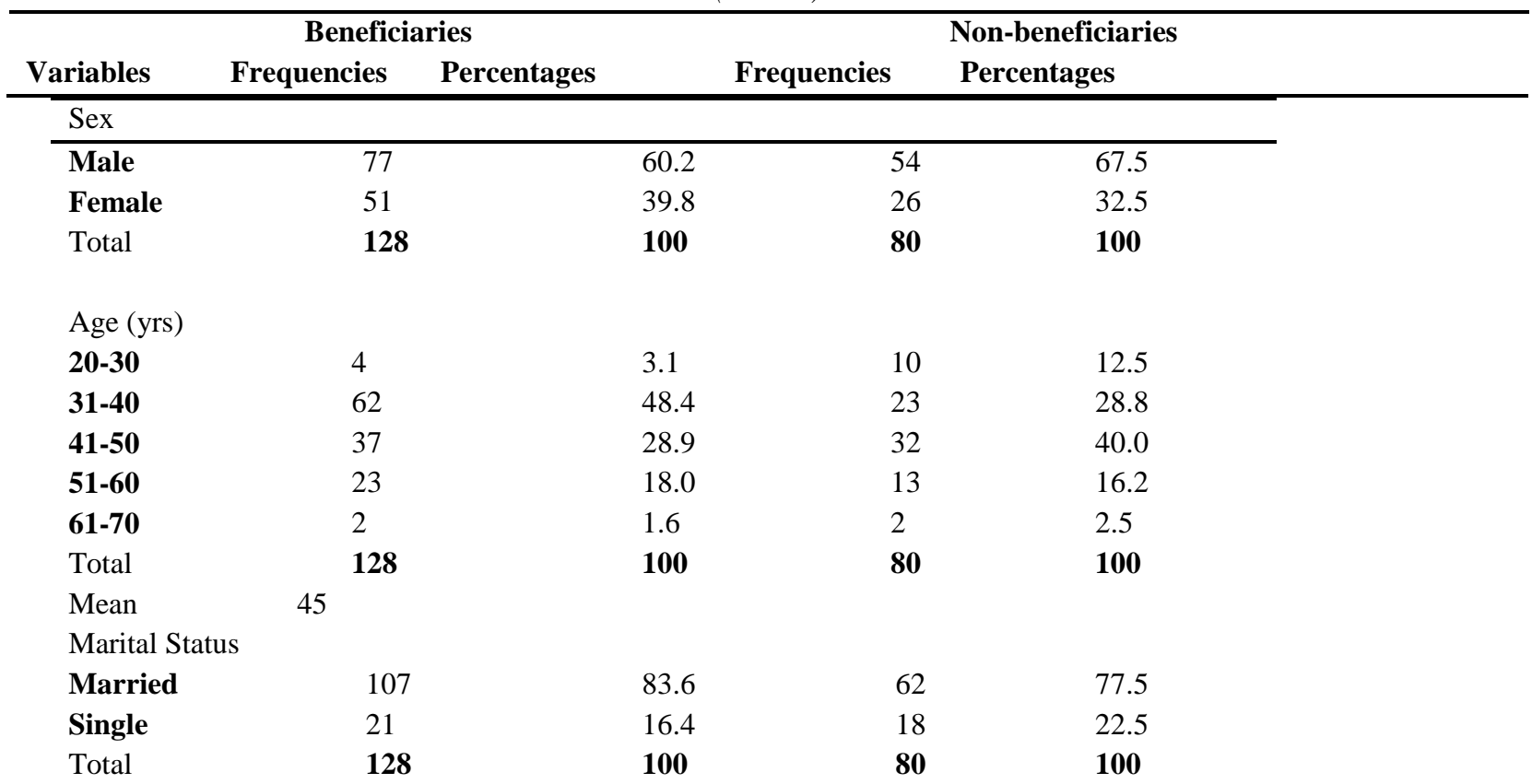

Education (yrs)

\begin{tabular}{|c|c|c|c|c|}
\hline 0 & 10 & & & \\
\hline $1-6$ & 43 & & & \\
\hline $7-12$ & 60 & & & \\
\hline 13-18 & 15 & & & \\
\hline Total & 128 & & & \\
\hline \multicolumn{5}{|l|}{ Hhsize } \\
\hline $1-5$ & 44 & 34.4 & 16 & 20.0 \\
\hline $6-10$ & 73 & 57.0 & 49 & 61.2 \\
\hline $11-15$ & 8 & 6.2 & 6 & 7.5 \\
\hline $16-20$ & 3 & 2.3 & 9 & 11.2 \\
\hline Total & 128 & 100 & 80 & 100 \\
\hline
\end{tabular}

12.5

38.8

33.8

15.0

100

Source: computed from field survey data, 2017. 
Poverty status of Beneficiaries and Non-beneficiaries of SACCO credit

The determination of poverty incidence index of beneficiaries and non-beneficiaries of SACCO credit a poverty threshold is established based on $2 / 3$ and $1 / 3$ mean per capita annual income (MPCFI) for beneficiaries and nonbeneficiaries of SACCO credit. Further, 2011 was taken as the year before obtaining credit and 2015 as the year after obtaining credit.

The poverty depth index for the beneficiaries is 0.16 before obtaining credit and 0.07 after obtaining credit, while that of the non-beneficiaries is 0.17 in 2011 and 0.11 in 2015. This implies that the non-beneficiaries had greater poverty depth index than the beneficiaries of SACCO credit. This can be said thus; the degree of poverty among non-beneficiaries was more compared to the beneficiaries. It therefore means that the farmers among the beneficiaries below the poverty line needs $\mathrm{N} 20,347.6$ annually which is 7 percent addition to their mean per capita annul farm income to attain the poverty line after obtaining credit. The non-beneficiaries will need 11 percent which can be translated to $\$ 31,974.8$ annually addition to their mean per capita annual farm income to attain poverty line.
It was found that the beneficiaries had a poverty severity index of 0.13 and 0.03 before and after obtaining credit. While the non-beneficiaries had poverty severity index of 0.11 and 0.05 in 2011 and 2015 respectively. The result showed that the beneficiaries had a higher percentage of 13 percent of the poorest before obtaining credit in 2011and a lesser percentage of 3 percent after obtaining credit in 2015 indicating reduction in poverty severity. The nonbeneficiaries had a poverty severity of showing that a higher percentage of 5 percent of poorest in 2015 compared to the beneficiaries. This implies that the credit obtained has a positive effect on the livelihood of the beneficiaries. It was found that poverty is marginally severe among respondents in the study area. About 3 percent of the beneficiaries constitute the poorest while about 5 percent of the nonbeneficiaries constitute the poorest among the respondents. This is in tandem with the findings of Adebayo (2004) who reported that though the participating bee farmers had larger number of poor, the degree of poverty among the nonparticipating bee farmers was more when compared with the participating bee farmers and poverty is marginally severe among the non-participants.

Table 2: Poverty status of beneficiaries and non-beneficiaries of SACCO credit

\begin{tabular}{|c|c|c|c|c|}
\hline \multirow[t]{2}{*}{ Poverty Category } & \multicolumn{2}{|c|}{ Beneficiaries } & \multicolumn{2}{|c|}{ Non-beneficiaries } \\
\hline & Before & After & Before & After \\
\hline Non Poor & $\begin{array}{l}72 \\
(56.25)\end{array}$ & $\begin{array}{l}86 \\
(67.19)\end{array}$ & $\begin{array}{l}76 \\
(95)\end{array}$ & $\begin{array}{c}77 \\
(96.25)\end{array}$ \\
\hline Moderate poor & $\begin{array}{l}31 \\
(24.22)\end{array}$ & $\begin{array}{l}38 \\
(29.69)\end{array}$ & $\begin{array}{l}0 \\
(0.00)\end{array}$ & $\begin{array}{c}2 \\
(2.5)\end{array}$ \\
\hline Core Poor & $\begin{array}{l}25 \\
(19.53)\end{array}$ & $\begin{array}{l}4 \\
(3.13)\end{array}$ & $\begin{array}{l}4 \\
(5)\end{array}$ & $\begin{array}{c}1 \\
(1.25)\end{array}$ \\
\hline FGT Poverty Indices & & & & \\
\hline Poverty Incidence (Po) & 0.44 & 0.33 & 0.05 & 0.04 \\
\hline Poverty Depth (P1) & 0.16 & 0.07 & 0.17 & 0.11 \\
\hline Poverty Severity (P2) & 0.13 & 0.03 & 0.11 & 0.05 \\
\hline
\end{tabular}

\begin{tabular}{l|l|l}
\hline Poverty Lines: & \multicolumn{1}{|c|}{ Before } & After \\
& $=\$ 270,169.00$ per annum & $=\$ 436,020.00 \mathrm{per}$ \\
MPCFI & $=\$ 180,112.00$ per annum & $=\$ 290,680.00 \mathrm{per}$ \\
$2 / 3^{*}($ MPCFI) & $=\$ 90,056.00$ per annum & $=\$ 145,340.00 \mathrm{per}$ \\
$1 / 3 *($ MPCFI) & & \\
\hline
\end{tabular}

Source: computed from field survey 2017 
Analysis of the Effect of Credit on Crop Output of Beneficiaries and Non-beneficiaries

Average output difference of the beneficiaries farmers was $3096.52 \mathrm{~kg}$ and $6032.98 \mathrm{~kg}$ before and after obtaining credit. Indicating that use of SACCO credit increased the crop output of beneficiary farmers. Furthermore, the average rice output for the beneficiary farmers was higher than that of non-beneficiaries after the SACCO intervention. The first single difference between after and before values is $2936.46 \mathrm{~kg}$. The mean output difference of the nonbeneficiaries of the SACCO credit before credit is $3618.13 \mathrm{~kg}$ and $5377.75 \mathrm{~kg}$ after obtaining the credit. The first single difference between the crop output values of the non- beneficiaries before and after credit is $1759.62 \mathrm{~kg}$. The difference between the first differences of the beneficiaries and non-beneficiaries is the double difference value. This is the difference between the two outputs differences (2936.46$1759.52)$ is $1176.84 \mathrm{~kg}$. The result simply implies that the double difference analysis of the crop output of beneficiaries and non-beneficiaries of the SACCO credit is a positive figure. This result according to the a priori expectation indicated that the SACCO credit obtained by rice farmers in the study area had a positive effect on the crop output of the beneficiaries of the credit. Nkonya et al., (2008) posited that a positive double difference in output value indicates a positive effect of credit on beneficiaries output.

Table 3: Double difference estimates of the of credit on crop output of beneficiaries and non-beneficiaries of SACCO credit

\begin{tabular}{|c|c|c|c|c|}
\hline \multirow[t]{3}{*}{ Group } & \multicolumn{3}{|c|}{ Crop Output } & \\
\hline & Before (kg) & After (kg) & Difference between & \\
\hline & & & Periods & \\
\hline Beneficiaries & 3096.52 & & 6032.98 & 2936.46 \\
\hline Non-beneficiaries & 3618.13 & & 5377.75 & 1759.62 \\
\hline Difference between groups & -521.61 & & 655.23 & 1176.84 \\
\hline
\end{tabular}

Source: field survey, 2017

The result of the hypothesis testing of crop output of the beneficiaries and non-beneficiaries showed that the F-value of the test had a positive value 21.197 and is statistically significant at one percent (1\%). The mean of the crop output difference had a positive value 655.23 , this indicate that there is a positive difference between the crop output of the beneficiaries and non-beneficiaries of SACCO credit. Therefore the null hypothesis which states that the use of credit has no significant effect on crop output of beneficiaries was rejected.

\section{CONCLUSION}

The analysis revealed that Savings and Credit Cooperatives have helped the members improve their livelihood. It has positively changed members' poverty status by improving the crop output of beneficiaries of the SACCO credit. Nevertheless, the beneficiaries and non-beneficiaries had some factors that limited their efforts towards poverty reduction. There is room to the reduction of poverty via the improvement of the crop output of the SACCO members in the study area.

\section{RECOMMENDATION}

i. It is very important for families to encourage the female folks to participate in SACCO to improve their crop output and farm income. Some families with 8 member household sizes are still in core poverty due to inactive female folks in the household.

ii. SACCO executives and the Government should develop strategies that will bring in more funding; loans and grants to the cooperative consequently enhance availability of credit to members. This will help members who are smallholder farmers to become big estate farm holders. It is also vital to poverty reduction due to its positive effect on the crop output and increase in per capita annual farm income.

iii. Community members should be encouraged to get formal education and also adopt extension trainings for bumper crop output and to enable them benefit from the credit of the SACCO.

\section{REFERENCES}

[1] Adebayo, A. and Yusuf, O.R. (2004). Cooperatives and Poverty Alleviation in Rural Settlement of Kwara State, Nigeria. 
[2] Adewakun, A. (2012), Cooperative as tool for enhancing financial inclusion, African Newspaper of Nigeria. Oct.13,P1.

[3] Ajaero C. (2007). A brand new image for Benue, Newswatch Magazine (Newswatch Communications). July 12,2007 from http://www.wikipedia.com

[4] Akende, S.O. and Akpokodje, G. (2003), Rice Prices and Market Integration in Selected Areas in Nigeria. Agriculture and Rural Development Department Research Report

[5] Albouy, David, 2010. Evaluating the efficiency and equity of federal fiscal equalization, Journal of Public Economics, Elsevier, vol. 96(9-10), pages 824-839.

[6] Alam G.M. (2009). Can governance and regulatory control ensure private Higher education as business or public goods in Bangladash? African Journal Business Management, 3(12), 890-906

[7] Almas H, 2013 The Relationship between Income Inequality and Globalization Retrieved July 7, 2010 from http://www.wider.unu.edu/

[8] Alam G.M., Khalifa. M.T.B and Shahajamal, M.M. (2009). Return from education system in Bangladash: an investigation on comparative flashback scenario. African Journal Business Management, 3(10): 567-575.

[9] Biyi, D. (2005). Government Policies and Competitiveness of Nigerian Rice Economy Paper represented at the "workshop on Rice Policy and Food Security in sub-Saharan Africa" organized by WADA, Cotonon, Republic of Benin, November $07-09,2005$.

[10] Bzugu P.M., M.M.Gwary, and Y.L. Idrisa, (2005).Impact of Extension Services on Rural Poverty Alleviation among Farmers in Askira/ Uba Local Government Area of Borno Sate. Shael Analyst, Faculty of Management Sciences, University of Maiduguri. PP96-103. Food Policy, 26, 4

[11] Goodluck, J. (2011). Job creation an urgent task; Punch Newspapers, Feb.24.

[12] Jones, M.P. (1995), the Rice Plant and its Environment West African Rice Development Association (WARDA) training Guide 2. P $1-16$.

[13] Magbagbeola, J.A.O., Adetoso, J.A and Owolabi, O.A. (2010) Neglected and Apicrutilizes Species (NUS):A panacea for community focused development to poverty alleviation/poverty reduction in Nigeria. Journal of Economics and international finance, 2(10):208-211.

[14] Mavinbela, P., Masuku, M.B. and Belete, A. (2010). Contribution of savings and credit cooperatives to crop production in Swaziland: A case study of smallholder farmers. African Journal of AgriculturalResearch; 5(21):2868-2874.

[15] Mwakajumilo. S.L.I (2011). The Role of Informal Microfinance Institutions in Savings Mobilization, Investment and Poverty Reduction. A Case of Savings and Credit Cooperative Societies (SACCOS in Tanzania From 19612008. Unpublished Doctorial Thesis. St Clement University, Turks and Caicos Islands of British West.
[16] Niemen, G., Hough, J. and Niewenhunizen, C. (2003). Entrepreneurship- A South African Perspective. Hatfield, Pretoria: Van Schaik Publishers.

[17] Nkonya, E., Philip, D., Mogues, T., Pender, J., Yahaya, M. Adebowale, G.J and Arokoyo, T. (2008). Impact of a pro-poor community-driven development Project in Nigeria PP 10-36 A report submitted to International food policy research institute on sustainable solutions for ending hunger and poverty.

[18] Oguntola, S.I (1988). Female-Oriented Technologies in Agricultural Research in Oyo State. Unpublished B.Sc Thesis in the Department of Extension and Rural Development, University of Ibadan, Nigeria

[19] Olorunsanya, E.O (2009). Gender of Household Heads and Relative Poverty among Rural Farming Household in Kwara State. An Unpublished PhD Thesis in the Department of Agricultural Economics and Farm Management, University of Illorin, Nigeria 